\title{
Hemşirelerde Duygusal Emek Kavramı Üzerine Nitel Bir Araştırma
}

DOI: 10.26466/opus.678995

\author{
* \\ Bünyamin Özgüles * \\ * Dr, Yunus Emre Devlet Hastanesi, Eskişehir/Türkiye \\ E-Posta: bunyas32@yahoo.com \\ ORCID: $\underline{0000-0002-8401-3620}$
}

$\ddot{O} z$

Duygusal emek kavramı kısaca, müşterilere karşı yapılması gereken davranış şekli olarak tanımlanmaktadır. Bu davranış şeklinin sağlık sektöründe özellikle de hemşirelik meslek grubunda oldukça fazla kullanıldığı bilinmektedir. Bu araştırmada sağlık sisteminin önemli bir unsuru olan hemşirelerde, çalışma yaşamında hizmet verirken oluşan duygusal emek davranışı hakkında derinlemesine bilgi edinilmesi ve duygusal emek davranışı ile ilgili sosyal gerçekliğin açıklığa çıkarılma isteği amaçlanmıştır. Bu hedef doğrultusunda nitel olarak fenomonolojik bir desen çerçevesinde oluşturulan yar yapılandırılmış görüşme formu ile Eskişehir ilinde faaliyet gösteren bir kamu hastanesinde görev yapan 9 hemşire ile görüşmeler yapılmıştır. Elde edilen bulgular içerik analiz yöntemi ile incelenmiş çeşitli yorum ve çıkarsamalarda bulunulmuştur. Araştırmanın temel bulguları kavramsal kodlamalar vasıtasıyla duygusal emek davranışı hakkında süreç alt boyutlar ve olumlu ve olumsuz etkileri şeklinde temalar ile betimlenmiştir. Araştırmanın bulgularından elde edilen verilerin değerlendirilmesi sonucunda duygusal emek gösteriminde öne çıkan duyguların, vicdan, merhamet ve hastanın tedavi anındaki durumunun da çok etkili olduğunun ifade edilmiş olmasıdır.

Anahtar Kelimeler: $\quad$ Duygusal Emek, Hemşirelik, Nitel Araştırma 


\title{
A Qualitative Research on Emotional Labor Concept in Nurses
}

\begin{abstract}
The concept of emotional labor is briefly defined as the behavior that needs to be done against customers. It is known that this behavior is used quite a lot in the health sector, especially in the nursing profession group. In this study, it is aimed to obtain in-depth information about the emotional labor behavior and efforts to reveal the social reality about emotional labor behavior in nurses, which is an important element of the health system, while serving in working life. In line with this goal, interviews were conducted with nine nurses work in a public hospital operating in Eskisehir, with a semistructured interview form created within the framework of a qualitatively phenomenological pattern. The findings were examined by the content analysis method, and various interpretations and inferences were made. The main findings of the study are illustrated by conceptual coding, the themes of process sub-dimensions, and positive and negative effects on emotional labor behavior. One of the analytical results of this study is that the emotions that stand out in emotional labor representation are expressed as very useful in conscience, compassion, and the patient's condition at the time of treatment.
\end{abstract}

Keywords: Emotional Labor, Nursing, Qualitative Research 


\section{Giriş}

Yaşamış olduğumuz dünyada tanımlanması en zor varlık olarak insanın en önemli özelliği olan duygu durumu ve insanların çalışma hayatındaki en değerli ve kutsal olarak kabul edilen emek kavramlarının birleşmesinden oluşan duygusal emek ile ilgili literatürdeki tanımlarından yapılan çıkarım müşterilere karşı yapılması gereken davranış şeklidir denebilir. İlk olarak Hoshschild (1983, s.7) tarafından kavramsallaştırılan ve çalışanlarda müşterilere karşı hissedilmeyen duyguları gösterme şekli olarak tanımlanan bu kavram özellikle hizmet sektöründe daha fazla konu edilmiş, sağlık alanında da oldukça fazla araştırma konusu olarak araştırılmıştır (Kıyat ve ark, 2018, s.489). Sağlık çalışanları denince ilk akla gelen meslek gruplarından olan hemşirelerin hastalara karşı göstermiş oldukları duygusal emek davranışı ve bu davranışın nasıl şekillendiği özelde sağlık çalışanları ile genelde ise tüm çalışma hayatı ile ilgilidir. Bu araştırmadaki temel hedef, hemşirelerin duygusal emek kavramı ile ilgili sosyal gerçeklik durumlarının araştırılması niyetiyle duygu ve düşüncelerini nitel analiz yöntemleri ile incelenmesidir. Bu kapsamda yapılan çalışma ile hastanelerde görev yapan 9 hemşire ile derinlemesine mülakat yöntemi ile araştırma desenlendirilmiştir.

\section{Duygusal Emek ve Kavramsal Çerçeve}

Duygusal emek kavramı ilk olarak Hoshschild (1983, s.7) tarafından ortaya atılmış ve çalışanlarda müşterilere karşı hissedilmeyen duyguları gösterme şeklinde tanımlanmıştır. Bu kavram yıllar içinde önemini artırarak, araştırmacıların oldukça ilgisini çekmiş, ulusal ve uluslararası yazında birçok araştırmacı tarafından incelenmiştir. Literatürde her kavram gibi duygusal emeğinde çeşitli araştırmacılar tarafından değişik tanımları yapılmıştır. Bu çalışmada araştırmanın konusu gereği, olgunun fonksiyonel tanımları yapılmak istenmiş olup bu tanımlamaların bazıları şu şekildedir: Chu ve Murrmann (2006, s.1183) mesleğin gerektirdiği kurallar ile toplumun oluşturduğu kurallar temel alınarak kişide oluşan duygu durumunu yansıtmak ve bu duygu ile davranışların duygusal olarak gösterilmesi olarak tanımlamış, Morris ve Feldman (1996, s.987) duygusal çelişki teorisi açısından, örgütün çalışanlarından bekledikleri duygusal gösterim durumu ile çalışanların içlerinden geldiği gibi göstermiş oldukları duygusal gösterim arasındaki 
farkı belirterek, bu duygu durumunu gösterirken gerekli olan çaba, kontrol ve planlamadan bahsetmektedir. Yine bir başka araştırmada Gabriel ve ark. (2016, s.22) çalışanların duygusal emek davranışından motivasyonları ve verimliliklerinin etkilendiğini iddia etmişlerdir. Duygusal emek fikrini ilk öne süren sosyologlar ise müşterilere karşı gösterilen davranışın yüzeysel (sahte) olarak gösterildiğini ifade etmiş ve duygusal emeği bir ürün olarak tanımlamıştır. Yukarıdaki fonksiyonel tanımlardan da anlaşılacağı üzere duygusal emek işin gereklilikleri ve/veya işverenin istediği şekilde çalışanlar tarafından hizmet verilen kişi veya kişilere karşı gösterilen ve emek gerektiren bir duygu durumudur şeklinde de tanımlanabilir (Hochschild 1983, s.7-9).

Duygusal emek kavramını araştırmacılar farklı şekillerde boyutlandırmışlardır. Morris ve Feldman, (1996, s.987); bu boyutları duygusal gösterimin sıklığı, gösterimin kuralları için sarf edilecek dikkat ve gösterilmesi gereken duyguların çeşitliliği ile duygusal uyumsuzluk şeklinde ele almışlardır. Bu boyutları örneklendirmek gerekirse duygusal gösterim sıklığ kasiyerlerin her müş̧teriye göstereceği duygu durumlarının tekrarı olarak, duyguların çeşitliliği ise sağlık çalışanlarında hastaların durumlarına karşı oluşan duygu durumunu gösterme, duygusal uyumsuzluğa örnek ise polislerin suçlulara karşı sert ifadeler göstermesine karşın çalışma arkadaşlarına samimi ifade göstermesi örnek verilebilir (Morris ve Feldman, 1996, s.987).

Kıyat ve arkadaşları (2018) tarafından yapılan çalışmada ağır hastaların kaldığ olduğu şeklinde ifade etmiştir. Buna ek olarak özellikle poliklinik hastalarından bazıları periyodik muayene ve sağlık raporu almak durumunda olduğu için sağlık çalışanları açısından hasta algısı oluşmadığından dolayı samimi davranış gösterme eğilimleri olduğu değerlendirmektedir (Kıyat ve ark, 2018, s.489).

Hoshschild (1983) tarafından ortaya atılan ve çalışanların müşterilere karşı hissedilmeyen duyguları gösterme şeklinde tanımlanan bu kavram ile ilgili çeşitli araştırmacılar tarafından modellerin ve alt boyutlarının ortaya konduğu gözlenmiştir. Yapılan çalışmalar ışığı altında aşağıda sunulan dört temel modelin daha çok ilgi gördüğü gözlenmiştir.

- Hochschild Modeli (1983).

- Ashforth ve Humphrey Modeli (1993).

- Morris ve Feldman Modeli (1996). 
- Grandey Modeli (2000).

Yukarıdaki modellerin kapsamlı incelemesi yapıldığında duygusal emek davranışı ile ilgili üç alt boyut vardır bunlar; yüzeysel rol yapma, derin rol yapma ve samimi duygular şeklindedir. Yüzeysel rol yapma ve derin rol yapma, duyguların belli bir amaç uğruna manipüle edilmesine odaklanmış iken, doğal olarak hissedilen duygu (samimi duygular) kendiliğinden olan ve gerçek duygulara dayanmaktadır (Basım ve Beğenirbaş, 2012, s.77).

Duygusal emeğin etkileri: Çalışanın işini yaparken sahip olduğu olumlu duygu ve düşünceler özel sektör ve kamu sektöründe "müşteri memnuniyeti" şeklinde geri dönüşlere sebep olmaktadır. Bu sebeple, müşteri memnuniyetini artırmak isteyen kurumlar, çalışanlara performansa dayalı ödeme, maaş, prim vb. gibi uygulamalara başlatmışlardır. Bu yönüyle "duygusal emek" kavramı hem çalışanlar hem de örgütler üzerinde olumlu/olumsuz sonuçları içeren psikolojik birtakım çıtılara neden olmaktadır (Aslan ve Çaldağ, 2011, s.39; Oral ve Köse, 2011, s.473; Seçer, 2012, s.265). Duygusal emek kavramının hem çalışan hem de örgüt için olumsuz sonuçları süreç içerisinde oluşabilir. Örneğin, çalışanlardan beklenilen duygusal emek kavramı, çalışanları müşterilerden uzaklaşarak onları birer nesne olarak görmelerine sebep olacaktır. Bu durum ise, başarısızlık ve duyarsızlaşmaya neden olabilmektedir (Kulualp ve Sarı, 2018, s.1172). Kaya ve arkadaşları (2017, s. 62) yapmış oldukları çalışmada duygusal emek gösterimi ile ilgili davranış çeşitlerinin zamana, duruma ve yere göre değişebileceğini bulgulamışlardır. Örgüt yöneticileri, duygusal emek davranışlarını ve bu davranış modelini çalışanlara vereceği eğitimler yoluyla kazandırıp örgütün genel verimliliği ve başarısını arttırmaya katkı sağlayabileceğini ifade etmektedirler (Hochschild, 1979, s.572; Seçer, 2005, s.814-815). Duygusal emeğin birçok çalışmada bağımlı, bağımsız, aracı, düzenleyici gibi birçok değişkenle ele alınan birçok nicel çalışma mevcuttur. Grandey'nin (2000, s.101) duygusal emek davranışını kapsamlı olarak sunduğu model incelendiğinde duygusal emeği girdileri ve çıtıları açısından çok değişkenli bir yapı olarak duygusal olaylar ile kişisel ve örgütsel faktörlerin oluşturduğu görülmektedir. Bu bağlamda araştırmanın kuramsal çerçevesini Grandey'nin (2000) modeli oluşturmaktadır. İnsan davranışları ile ilgili kavramsal konularda birden fazla değiş̧keninin olması konunun çok boyutlu olması ve tek bir çalışma ile bu konular hakkında tam anlamıyla bilgi sahibi olunması nere- 
deyse imkânsızdır. Duygusal emek ile ilgili sağlık alanında nicel olarak Gök, (2015, s.292) ilaç mümessilleri ile ilgili, Oral ve Köse (2011), Uzuntarla (2015) ise hekimler ile ilgili anket yöntemi kullanarak araştırmalarda bulunmuştur. Buna karşın Kulualp ve Sarı (2018,s.1167) okul öncesi öğretmelerin duygusal emek davranışını incelediği nitel çalışmada duygusal çelişki, rol yapma, duygu yönetimi, duyguların bastırılması, olumlu izlenim kategorileri ile almıştır. Kaya ve arkadaşları $(2017$, s.62) tıbbi sekreterler ile yapmış oldukları nitel çalışmada duygusal emek gösterimi ile ilgili davranış çeşitlerinin zamana, duruma ve yere göre değişebileceğini bulgulamışlardır.

Literatürdeki yapılmış olan çalışmaların birçoğu nicel yöntemlerle ve anket aracilığ ile incelendiği, nitel araştırmaların ise azlığ1 dikkat çekmektedir (Kıyat ve ark., 2018, s.477). Bu araştırmada yarı yapılandırılmış görüşme tekniği kullanarak görüşmelerin yapılması katılımcıların konu hakkında bilgi görüş deneyimleri hakkında bilgi edinmek ve duygusal emek kavramı ile ilgili sosyal gerçekliği açıklığa kavuşturma isteği bu araştırmanın önemli bir özelliğidir. Bu gerçeklik ve hedefler doğrultusunda Araştırmanın temel problemi ve çalışma grubuna sorulacak olan sorular iki ana soru başlığı şeklinde oluşturulmuştur;

A. Duygusal emek davranışı katılımcılar açısından nasıl bir anlam taşımaktadır?

B. Duygusal emek gösteriminde bireysel ve kurumsal değişkenler nelerdir?

\section{Araștırmanın Amacı ve Yöntemi}

Hemşireler hastalarla en fazla zaman harcayan ve iletişim kuran meslek grubudur. Bu iletişim ve zaman içerisinde çalışanlar duygusal emek gösterirken gerekli olan çaba kontrol ve planlamanın yanında duygusal emeğin alt boyutları olan yüzeysel, derin ve samimi davranış sergilemektedirler. Hemşirelerin hastalar ile ilgilenirken hem fiziksel hem de zamansal olarak daha fazla emek harcaması ve duygusal emek gösterimi sebebiyle gösterilen bu duygusal emek davranışı hakkındaki duygu, düşünce ve becerilerinin incelenmesi yönetilmesi ve farkında lı̆̆ının arttırılması neticesinde elde edilecek kazanımlar hem bilim dünyasına hem de sektöre fayda sağlayacağ değerlendirilmektedir. Bu amaçla anket çalışmalarındaki kısıtları ortadan kaldırmak, derinlemesine araştırma yapmak düşüncesiyle fenomenolojik 
olarak bireyin yaşam dünyasını ve deneyimlerini tespit etmek (Çoşkun, 2019, s.4) için fenomonolojik desen seçilmiştir.

Araştırmanın ilk bölümünde yarı yapılandırılmış derinlemesine mülakat esnasında katılımcılara sorulacak olan soruları belirlemek için ön çalışma yapılmış bu aşamada araştırmacının dışında alanında uzman üç akademisyenden görüş alınmıştır. Aynı hastanede görev yapan 21 katılımcı ile duygusal emek gösterimi hakkındaki görüşlerini belirlemek amacıyla açık uçlu sorulara verilen cevaplardan elde edilen veriler içerik analizi yöntemi ile belirli kategoriler ve temalar oluşturulmuştur. $\mathrm{Bu}$ analiz sürecinde literatüre uygun olarak duygusal emeğin süreçleri olan; çaba kontrol ve planlama, boyutlar olarak; yüzeysel, derin ve samimi son olarak da sebepleri ve sonuçları açısından spontan, durumsal, mutluluk, tükenme, merhamet, şeklinde 3 ana tema ve 12 kod belirlenmiştir. Bu bilgiler çerçevesinde görüşmecilere mülakat esnasında sorulacak olan sorular aşağıdaki şekilde oluşturulmuştur.

1. Duygusal emek kavramın daha önce duydunuz mu? Sizce bu kavram ne anlama gelmektedir?

2. Kurumunuz tarafindan hastalara karşı gösterilmesi gereken davranış şekilleri ile ilgili girdileri var mıdır? Varsa nelerdir (eğitim, telkin gibi) ve ne şekildedir.

3. Sizce bireysel olarak hastalara karşı gösterilmesi gereken davranış şekilleri nasıl olmalıdır? Bu konu ile ilgili bilgi ve tecrübeleriniz var mıdır? Varsa ne şekildedir?

4. Duysal emek gösterimi esnasında duygusal olarak çaba, kontrol ve planlamanız nasıl oluşur.

5. Hastalarla ilgilenirken sahte davranışlar nasıl gösterilir?

6. Hastalarla ilgilenirken empati yapılabilir mi ve/veya nasıl yapılabilir?

7. Hastalarla ilgilenirken içinizden geldiği gibi davranma ne anlama gelir?

8. Sizce duygusal emek göstermenin sebepleri nelerdir? (neden böyle davranirız)

9. Sizce duygusal emek davranışı göstermenin sonuçları nelerdir? (bu şekilde davranmak neleri etkiler)

10. Sizi bu şekilde davranmaya iten içsel durumlarınız neler olabilir?

Çalışma Grubu: Mülakat tekniği ile yapılan araştırmalarda verilerin toplanmasında doğaçlama olunması ve örneklem büyüklüğünün azlığı sebe- 
biyle yanlış genellemeler yapılması tehlikesi bulunmaktadır (Kothari, 2004, s.116). Fakat mülakat tekniği araştırma konusu hakkında daha fazla ve derinlemesine bilgi edinme araştırmaya katılanlar hakkında ek bilgiler elde edebilme gibi avantajlar sunmaktadır. Nitel araştırmalarda kaç kişiyle görüşülmesi gerektiği ile ilgili bilim insanlarının farklı görüşleri vardır. Bu konuda, Johnson ve Christensen (2004)'a göre; 6-12 kişi; Morgan (1997)' göre; 6-10 kişi; Krueger (2000)'a göre; 6-9 kişiyle mülakatın yapılması yeterli görülmektedir. Aynı zamanda, nitel araştırmalarda seçilecek homojen örneklemde 6-8 kişiye 12-20 soru sorulması uygundur (Kuzel, 1992). Bu amaç ile Eskişehir ilinde bir kamu hastanesinde görev yapan en az on yıllık görev tecrübesi olan, hastalar ile doğrudan iletişimde bulunan ve fizik tedavi ve dahiliye kliniklerinde çalışan 9 hemşire çalışma grubu olarak ele alınmıştır. Çalışma grubundaki katılımcı hemşirelerden randevu alınmıştır, bu aşamada görüşülecek konu ile ilgili herhangi bir açıklamada bulunulmamıştır. Böylelikle katılımcıların, araştırılan konu hakkında önceden hazırlık yapmaları engellenmek istenmiştir, mevcut duygu durumlarının gerçek durumu yansıtması amaçlanmıştır. Çalışmada örneklem yöntemi olarak olasılıklı olmayan örneklem çeşitlerinden biri olan amaçlı örneklem yöntemi (Gürbüz ve Şahin 2014, s.128) kullanılmış ve 3 farklı klinikte görev yapan 9 hemşire araştırmaya dâhil edilmiştir. Bu çalışmada araştırılan olguya ait görüşülecek kişi sayısı farklılık göstermekle birlikte kişi sayısının fazla olması değil kişilerden elde edilen bilgilerin kalitesi ve niteliği üzerine yoğunlaşmak istenmiştir (Baş ve Akturan, 2013, s.90).

Çalışmada nitel araştırma yöntemlerinden yarı yapılandırılmış görüşme tekniği ile derinlemesine mülakat yapılmıştır. Derinlemesine görüşme, açık uçlu, keşif yapmak amaçlı bir metottur (Baş ve Akturan, 2013, s.111). Görüşmede, kişilerin karmaşık duygularını anlamaya çalışmak, amaçlanır. Aynı zamanda bu görüşmeler ile katılımcıların deneyimleri hakkında bilgi edinilmeye çalışılır (Erdoğan vd., 2014, s.145). Çalışmanın amacına uygun olarak araştırmacı tarafindan hazırlanan yarı yapılandırılmıs soru formu kullanılmıştır. Yarı yapılandırılmış görüşmeler ile katılımcının algılamış olduğu dünyayı kendi ifadeleri ile anlatmasını sağlamak amaçlanmıştır (Merriam, 2013, s.88). Bu amaçla katılımclardan ilgili onam formu alınarak tamamen gönüllülük esasına göre Kasım-Aralık 2019 ayları arasında görüşmeler yapılmıştır. Böylece problem hakkında tüm sorular ve boyutların ele alınması hedeflenmiştir. Katılımcıların kendilerini tanıtan (yaşı, cinsiyeti, 
eğitim durumu, toplam görev süresi) bilgiler (4 soru), duygusal emek davranışları ile ilgili görüşlerini almak amacıyla sorular yöneltilmiştir. Gerekli durumlarda, konuyu daha iyi anlamak için hastalarla yaşamış diyalogları ve duygu durumlarını anlatmaları istenmiştir. Bu sorular ile ilgili olarak alanında uzman üç kişiden görüş alınmıştır. Bu da ölçme araçların geçerliliği ile ilgili bir kanıt olarak kabul edilmiştir. Görüşmeler katılımcıların isteklerine göre hastane, işyeri ve ev gibi farklı mekânlarda gerçekleştirilmiştir. Görüşmede veri kaybı olmaması düşüncesiyle görüşmecilerden izin alınarak ses kaydı yapılarak ses kayıtları metin haline getirilmiştir. Metin haline getirilen metinler görüşmecilere tekrar redakte ettirilerek farklı anlamlara gelebilecek metinler düzeltilmiştir. Görüşmeler hemşire 1,2, ifadesi şeklinde kısaltmalar yardımı ile H1,H2, ... şeklinde kodlanmıştır. Katılımcılara ait demografik değişkenler aşağıdaki tablo 1 de sunulmuştur.

Tablo 1. Katılımcılara Ait Demografik Değisskenler

\begin{tabular}{lllll}
\hline & YAŞ & CINSİYET & EĞİTiM DURUMU & KIDEM \\
\hline H.1 & 44 & Kadın & Yüksek lisans & 25 \\
\hline H.2 & 38 & Kadın & Lisans & 18 \\
\hline H.3 & 33 & Kadın & Lisans & 21 \\
\hline H.4 & 44 & Kadın & Yüksek lisans & 26 \\
\hline H.5 & 43 & Kadın & Yüksek lisans & 21 \\
\hline H.6 & 41 & Kadın & Lisans & 21 \\
\hline H.7 & 40 & Kadın & Yüksek lisans & 18 \\
\hline H.8 & 42 & Kadın & Yüksek lisans & 19 \\
\hline H.9 & 41 & Kadın & Ön lisans & 20 \\
\hline
\end{tabular}

Verilerin analizi: Elde edilen veriler ilk olarak araştırmada topladığımız verilerin özellikli olan bazı ifadeleri özgün formunda değişiklik yapmadan katılımcıların söyledikleri şekliyle herhangi bir değişiklik yapmadan direk alıntı yapılarak betimsel bir yaklaşımla veriler sunulmuştur.

Bu çerçevede literatür ışığı altında metinler incelendiğinde 21 betimlemeden aynı anlama geldiği düşünülen kelimeler çıkarılmış ve 12 kod belirlenmiştir. Bu kodlar da süreç boyut ve sebep sonuç olarak temalandırma yapılmıştır. Daha sonra ilk yaklaşımı da içerecek şekilde açıklayıcı çıkarsamalarda ve yorumlamalarda bulunulmuştur. Bir başka deyişle betimsel ve içerik analizi yöntemiyle veriler analiz edilmiştir. Araştırmanın iç geçerliliği için alanında uzmanlarca incelemesi, katılımcıların teyidi, bulguların doğrudan alıntılar ile verilmesi ve bulguların ilgili alan yazınla tutarlılığı yar- 
dımıyla sağlanmaya çalışılmıştır. Betimsel analiz ile elde ettiğimiz verileri kavramsal çerçevedeki kodlar ve temalara göre tablolaştırıp özetlenerek yorumlama yapılmıştır. Katılımclara görüşmenin başında duygusal emek kavramını daha önce duyup duymadıkları sorulmuş ve katılımcılardan 6 katılımc bu kavramı duymadıklarını 3 katılımcı ise duyduklarını belirtilmiştir. Bu çerçevede tüm katılımcılara duygusal emeğin kısa tanımlamaları ve örneklendirmeleri yapılarak görüşmeye devam edilmiştir.

\section{Bulgular}

Mülakat esnasında sorduğumuz sorular duygusal emek kısmının kavramsal çerçeve kısmında da bahsedilen konu ve temalar ışığı altında değerlendirilmiş ve duygusal emeğin boyutları olan yüzeysel davranış samimi davranış ve derin davranış şekilleri, duygusal emek gösterimindeki planlama çaba ve kontrol duygusu ve duygusal emek göstermenin sebepleri ve sonuçları gibi genel anlamıla ifade edildiği ayrıca vicdan ve manevi duygular kategorisinde de oluştuğu gözlenmiştir.

Tablo 2. Kod ve temalarn görüşmecilere göre farklılıklar

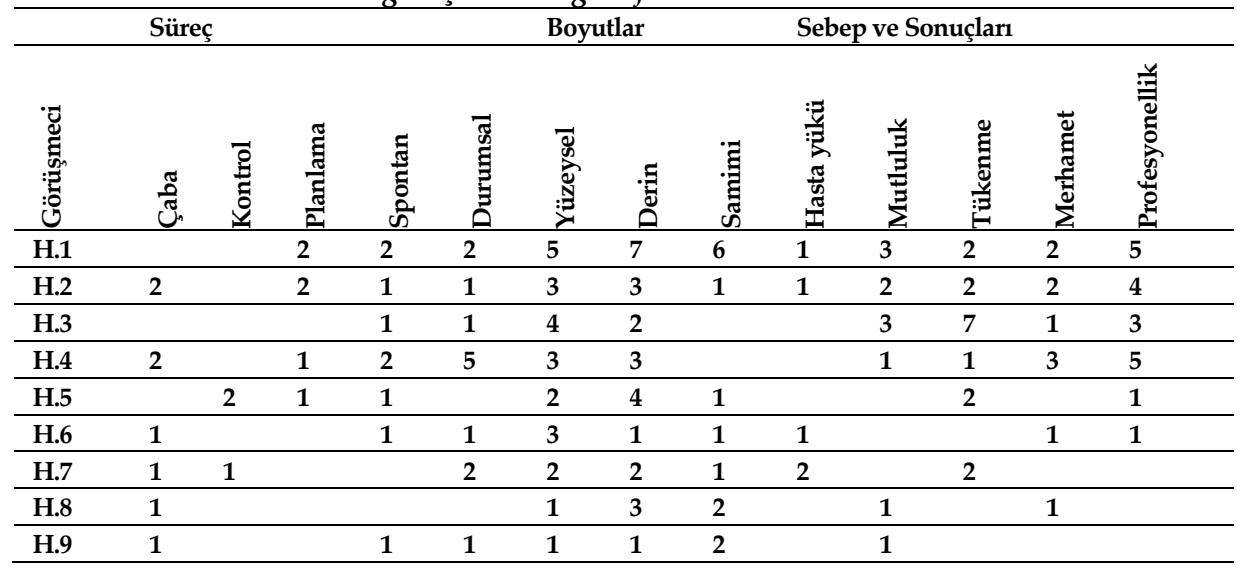

Tablo 2 incelendiğinde kodların ve temaların hepsini birden ifade eden görüşmecinin yüzeysel ve derin davranış konularında fikir verdiği görülmüştür. Kontrol, planlama, hasta yükü, kodlarını diğer kodlamalara göre daha az olduğu görülmüştür. 
Süreç: Duygusal emek gösterimi esnasında yapılan ve gerekli olan çaba kontrol ve planlama, duygusal emek gösterimi süreçlerini ifade etmektedir (Morris ve Feldman, 1996,s.987). Çalışmanın bu bölümünde çaba, kontrol ve planlama kodlarına ait kısmı süreç teması olarak nitelendirdiğimizde katılımcıların bu durumu ifade eden düşünceleri ele alınmıştır.

- H.1: "duygusal emek böyle bir programlanmış bir davranışşekli değildir, duygusal emek insanın kendinden kaynakl olur, sen bu duygusal emeği ben bu hastaya gidince duygusal emek gösteriyim, şu şekilde davranayım demiyorsunuz o an hastanın yaşadığı şeyler sizi etkiliyorsa zaten siz o duygusal emeğ $i$ gösteriyorsunuz ve kendiliğinden gelişen bir şeydir.

- H.2: "Ayrica hasta çok üzülüyor işte çok ağrım var diyor sende doktora tekrar gidiyorsun soruyorsun hastanın çok ağrısı var geçmemiş diyorsun tekrar ağrı kesici yapmak istiyorsun bunu doktorla paylaşıyorsun. Aslinda bir planlama değil de kendinden gelişen bir şey hastanın duygusundan ve ağrısından dolayı sende bir şeyler yapabilirmişsin diye çabalıyorsun tabii ki"

- H.6: "aniden gelişiyor ama 21 yllhk hemşireyim yani bir bilgi ve tecrübe birikimim var çok şükür yeteneğim sağh̆ğım yerindeyken bunları yapabiliyorum evet planlama kontrol yapabiliyorum çok şükür"

Bu durumda H.1, H.6 ve H.2 ye ait ifadelerde duygusal emek gösteriminin hem süreç esnasında hem de durumsal olduğunu ve bazen de kendiliğinden oluştuğunu ifade ediyor.

- H.4: "mesela şehit ailelerine gittiğimizde durum çok farkl, benim inanışım gereği benim inançlarımda ağlamak yakınmak yoktur benim dini inanışım böyledir ama oraya gittiğinizde ağhlyorlar dövünüyorlar ona da saygı duymam gerekiyor ama oradaki insanlara bunu yapmaniz yanlış demiyorum bundan da hoşlanmıyorum ama ses çıkartmıyorum tepki de göstermiyorum tam da bu durumda çaba kontrol planlama oluyor." Diğer ifadesinde "Meslek bunu gerektiriyor ben daha çok bunu seçici davranış olarak nitelendiriyorum, çünkü herkesin sosyal kültürel seviyesi bir değil sosyal ekonomik seviyesi bir değil hepsinin beklentileri bir değil onu ölçüp tartarak ona göre yaklaşmak hastadan çok hastalik gibi hikâyesi oluyor kişide bireysel olarak".

- H.5: "yani bir hastaya başka başka bir hastaya başka davrandiğım oluyor başka bir deyişle adamina göre şerbet misali davrandığım oluyor". Diğer ifadesinde "bizim kliniğe yatan hastalar en az birkaç ay yatan hastalarmız var düşünün zaten bu insanlar bizim bölüme yatıyorlar adam uzun süre yatacağın biliyor 
sen bu hastaya kötü davrandiğın anda zaten adamın morali bozuk çünkü bizim hastalar diyabetik ayak ya parmağı kesilecek ya diz altı ampüte olacak ya kalçadan ampüte edilecek hastalar zaten psikolojik olarak diplerde sen şimdi ona kötü davrandiğın zaman ya da sorularım cevaplamadığın zaman asık suratl davrandığın zaman ister istemez zaten adam çökkünlük yaşıyor üstüne iki kat çökkünlük yaşar hastanın durumuna göre değişiyor davranma sekli".

- H.7: "ben çok fazla bastıriyorum evet bazen o kadar absürt istekler de bulunuyorlar ki evlerinde bulamadiklan istekleri sizde istiyorlar. Bunlar gerçekten bitiriyor tahammül stnırlarm zorluyor, ben ne yapıyorum, bu durumda kendimi zaten zor tutuyorum, 3 e kadar 5 e kadar saymalarm var zaten bu kişileri gördü̆̆̈̈m zaman görmezden geliyorum, kendimce yaptığım çabalar onlar oluyor yada bazen tabi ki diyorum çünkü anlamıyor hayırdan anlayan insanlar değil, yapacağız tabî̀ ki yapacă̆ız zaten elimizden geleni yapıyoruz ama yok doyulmuyor, insanlar doyumsuz bir hale geldi anlamadım, bir de sistem öyle yaptı $\mathrm{ki}$ her zaman hasta haklddra getirdi sürekli bir hasta artsın hasta artsin diye zaten ful aksesuar çalışıyoruz, insanlar ney için çalışıyor para için değimli, kimse keyfinden gelip yapmiyor zaten para insanları memnun edecek seviyede de değil en azından ikili ilişkilerimiz iyi olsun ki insanlar onunla motive oluyor ama biraz idare bizim yanımızda değil" diğger ifadesinde "yok artık meslek tecrübesi mi dersiniz yüzüne yansiyor anliyorsunuz zaten ben de ona göre davranyorum o kişi gerçekten samimi biliyorum, kimisi var bu durum arkadaşlarında da oluyor bazısı var sorumlu olduğun için sana yağcllik yaptyor anllyorsun kimisi de gerçekten içten gelerek sana iltifat ediyor mesela, anliyorsun gerçekten sevdiği için diyor diyorsun"

- H.8: "tabii şimdi hasta birkaç parmağın kaybetmişs ayağı da kesilecek ben ona ne kadar destek olabilirim, ne kadar aman boş ver geçer diyebilirim o zamanlarda çok zorlanıyoruz tabii çaba sarf ediyorsunuz, beni en çok zorlayan o tesellisi olmayan şeyler yaşayabiliyorsun yani metanetli ol bu da geçer dediğinizde anlamli olmuyor"

H.7 ve H.8 duygusal emek gösterimindeki çaba ve kontrolden bahsediyor aynı zamanda bu durum hastanın durumuna göre de şekillendiğini ifade ediyor.

Genel olarak süreç teması ile ilgili İfadeler incelendiğinde görüşmeci H.1, H.2, H.4, H.5, H.6, H.7, H.8 bu durumda hastalar ile ilişkisinde ve bu süreç esnasında durumsal olduğunu ifade etmektedir. Ayrıca süreç esnasında 
çaba planlama ve kontrol duygularının öne çıtığını ve süreç esnasında duygusal olarak tükendiklerini de ifade ediyorlar, ayrı bir durum olarak özellikle görüşmeci H.4 bu duygu durumlarında mesleki gereklilik olduğunu durumsal yaklaşımlardan bahsederek spontane gelişime de uyduğunu söylüyor.

Boyutlar: Duygusal emek alt boyutları açısından incelendiğinde yüzeysel derin ve samimi duygular şeklinde ifade edilmektedir (Basım ve Beğenirbaş, 2012,s.77; Hochschild 1983,s.7-9). Bu çalışmada bu boyutları ifade edecek cümleler aşağıda ele alınmıştır.

- H.1: "Hastaya karşı davranışı, sempatik tavırları, işine göstermiş olduğum emek bunlarn hepsi duygusal emeğin içinde geçiyor diye düşünüyorum, hastanın canının çok sıkıldığıı düşünüp etkinlik planladım"

- H.2: "Empati yapryorum o yatak da kendim yatryor gibi hissediyorum bazen tedavi yaparken odaya girdiğimde, o hissi yaşamaya çalışıyorum. Mesleğin gerektirdiği davranışları çoğu zaman rol yaparak sahte duygular sergiliyorum, rol gereği yapıyorum, sizi çok iyi anlıyorum gibi ifadeler kullaniyorum."

- H.3:"Hasta seni negatif etkilediği zaman sende negatif ve sahte duygular sergiliyorsun. Empati yapmadan olmaz"

- H.4: "Duygulardan tamamen arındırılmış bir şekilde, ya bizim başımıza da bu durum gelseydi diye düşünüyorum, mesela çok üzülüp sevinebilirsin ama bunları maskeleyerek iş hayatında o şekilde yaşayabilirsin"

Yukarıdaki ifadeler incelendiğinde görüşmecilerin sadece bir davranış şekli ile yetinmeyip duruma göre farklı davranış sergiledikleri ve duygularını duruma göre eş zamanlı planladıkları anlaşılıyor.

- H.5: "Tabii sahte davranışı ister istemez sergilemek durumunda olduğunuz durumlar oluyor örnek bir tane hasta aslinda hastayla ilgili bir sikıntı yok ama hastanın yakın acayip agresif hasta yattı yatalı hemşireye karşı olsun doktora karşı olsun personele karşı sürekli bir kavga eğiliminde sürekli ses tonu yüksek bu hasta baştan beri böyle size kötü davranıyor sizde kötü davransanız kavga çıar bu durumda mecburen o hastaya sinir olsan dahi nefret boyutunda değil de davranışın onaylamasan dahi mecburen o hastaya iyi davranmak güler yüzlü davranmak zorundasm" 
- H.6: "Samimi davranış kullanıyoruz tabi ki tepkisiz kalmıyoruz mecbur kullaniyoruz hasta bir şey dediğinde hastanin tepkisine göre bende tepki gösteriyorum içimden geldiği gibi hasta samimi davrantyorsa bende samimi davranıyorum hasta bana fikra anlatıyor bende fikra anlatıyorum. O günkü duruma göre samimi davranırsa samimi, yüzeysel davranırsa yüzeysel davranıyorum durumsal aslında bu davranıs da ama sinırımı her zaman korurum"

- H. 9: "İçimden gelerek yaptığım için mutlu oluyorum karşımdakini de mutlu etmiş oluyorum sahte yapsam beni mutsuz ederdi zorunlu yapmıs olurum o zaman müziği açıyorum hasta odasina giriyorum mesela ona de enerji veriyor o anlik derdini unutuyor hastada"

İfadeler incelendiğinde görüşmeci H.1,H.2,H.3,H.4,H.5,H.6,H.9 duygusal emeğin boyutlarından bahsetmiş olmakla birlikte bu durumun durumsal ve süreç ile ilgili olduğunu ifade etmişlerdir. Ayrıca samimi davranmanın kendisini mutlu ettiğini ifade ediyor bu durum sadece olumsuz değil olumlu etkilerine de bir örnek olmaktadır.

Sebep ve Sonuçlarn: Yapılan çalışmalara duygusal emeğin sebepleri ve sonuçları açısından bakılmış ve çalışanlarda olumlu ve olumsuz etki ve sonuçları olduğu görülmüştür (Aslan ve Çaldağ, 2011,s.39; Oral ve Köse, 2011,s.473; Seçer, 2012,s.265). Bu çalışmada ise sebep ve sonuçlar hasta yükü, mutluluk, tükenme, merhamet profesyonellik başlıkları altında kodlanmış ve incelenmiştir.

- H.1: "Çok fazla sayıda hasta yatırılmış olması hastayı müşteri olarak görülmesi hastayla az zaman geçirilmesi samimi davranışlara engel olmaktadır. Bu yüzden dolayı da gerek bu hemşirelerde gerekse sağlık sunucularnnda tükenmişliğe neden oluyor, Mesleki tatmin çok önemli benim için bu da özellikle bizlerde ücret değil hastanın bir eline sağhlk, Allah razı olsun teşekkür ederim sözleri bizim için sağllk personeli için daha önemli, vicdandan ziyade Allah korkusu diyorum bu konuya dini duygularm diyorum tabii bir yaşlya hastaya yardım etmek vicdandan daha üst seviye olduğunu düşünüyorum bunun karşıllğın alabileceğimi düşünüyorum. Bu yüzden duygusal emek göstermemin samimi davranış göstermemin en büyük nedeni budur diye düşünüyorum" 
Görüşmeci H.1 kurumsal olarak hasta fazlalığı ve ücret konusunu ön plana çıkartmakla birlikte mesleki tatminin de öneminden olumlu geri bildirimlerden hoşlandığını ifade ediyor.

- H.2: "Vicdan ve merhamet çok etkiliyor, şu anda annesine bakan çocuk, çocuğuna bakan anne, eşine bakan amca hepsi de beni etkiliyor çok üzülüuorum yıpratıyor meslekle tecrübelendikçe yıpranmamayı öğreneceksin ama bu meslekte evet duygularmı katıyorsun, insanlarn normal hayatta görmediklerini sen sürekli görüyorsun kötü hasta seni etkiliyor"

- H.4: "Örnek olarak yaralayıcı vakalarm vardır mesela muhtemelen cinayete kurban gitti ama intihar olarak girildi ben tutanağımı tuttum koydum hala aklıma gelir. Çok üzüldüm hala aklıma gelir birkaç vaka vardır böyle ama işi iş de burakıp gitmeyi tercih ediyorum".

- H.5: "Bu kliniğe ilk başladığımda bir yatan hasta teyze vardı mesela sol bacak ampüte sağ bacak çok kötü genel durumu da bozuk, 1999 depreminde beş tane çocuğunu gelinini bir torununu hepsini kaybetmiş bir tane eşi kalmış ve sonrasında şeker hastası olmuş, kadın bu durumdan dolayı bacağını kaybetmiş vesaire durumu çok kötü şimdi bu durumda ister istemez hastaya üzülseniz bile ne duygusallik kalıyor ne merhamet kahlyor ne vicdan kahlyor herkes elbirliği ile o hasta toparlasın diye çok uğraşıyoruz ama başarll olamadık hasta yoğun bakıma gitti hastalarn $\% 80$ i bu şeklide zaten vicdanım kullanmaya kalksan buraya gelen hastalarm hepsinin yatırman lazım, bazılarn sana ă̆hıor üzülüyor ama yarası bizim hastaneye yatacak durumda olmayan hastalar var. Onlara hizmet veremiyorsun duygusal olmuyorum duygusal bir insan değilim beklide daha doğrusu duygusaldım yaşanmışlıklardan ötürü duygusallı̆̆ımı kaybettim, mesleğin bir sonucu olarak belki de ailemin dışındakiler için duygu ikinci planda kalıyor artı".

- H.6: "Birisi ile görüştüğümde hastaya yardımcı olduysam eğer vicdanım çok rahatlar benim ama bir şeyi eksik yaptım ya da yanlış yaptığımda kendimi sorgularım vicdanım sızlar şey yapamam ben bütün işimi yapmışımdır ama yine kötü bir şey olabilir vicdanım rahat derim, benim yüzümden kötü bir şey olmuşsa vicdanımı etkiler üzülürü̈m çok, neden yapmadım derim benim yüzümden olduysa şayet".

Görüşmeciler H.2, H.4, H.5 ve H.6 bazı ifadelerinde mesleki gerekliliklerden bahsetse de duygu durumlarından tamamen arınmış olmadıklarını 
üzüntü vicdan ve merhamet duygularının ön plana çktığını ifade etmişlerdir.

- H.7: Ne olabilir en çok insanlar artık suratsız geziyor yüzlerine yansıyor eve gidince canın sıkkm oluyor evdekiler bile anlıyor yani ne olduğunu en ufak bir şeye patluyorsun, o olabilir, tükenmişlik oluyor tahammül sinırlarm bitiyor çocuğuna bağırıyorsun ondan çıkarıyorsun o olabilir psikolojik olarak da fizyolojik olarak da etkiliyor oran buran ağrryor başın ağriyor mesela stres ă̆rilarım çok oluyor bende başım çok ă̆rryor gerilim ağrnlarım çok oluyor sır ağrilarım çok oluyor mide ağrım çok oluyor eskiden mide ağrısı bilmezdim asit arttığı için midem çok ağrıyor. Diğer bir ifadesinde "Vicdanlı olduğuma inanıyorum ama karşı taraftan nasıl gözüküyor bilemem ama vicdan giriyor bence bazen karışmaym diyorsun ne hali varsa görsün diyorsun ama yapamiyorsun vicdanin deoreye giriyor, hep yardımcı oluyorum yani sonuç da zararda görsem hep yardimcı olmaya çalışııorum vicdanım devreye giriyor".

- H.8: "İnsan olmann gereği bence benim evde yaşadığım bir problemi burada yatan hastaya yansitmamin alakası yok. Bu ayrımı iyi yapmak lazım etik değerlere bakmak lazım insani olarak iyi bir hemşire olmak için ve bu işi iyi yapabilmek için gerekli diye düşünüyorum. Bu da bir özveri zaten duygusal emeğin için de özveri de var hastanın hakkı bir de bence burada hiç kimse yatarken asık suratlı hastayı azarlayan birsini istemez herhalde nemrut bir insanı çekmek zorunda değil onun için hastanın da hakkı var diye düşünüyorum".

- H. 9: "Hastaya denileni yapmadığı zaman tedavisini takip etmediği zaman kızıyorum aslinda hani bunu çok belli etmiyorum mesela seker hastası diyetine dikkat etmesi gerek şeker çok yüksek çıkıyor. Ama biliyorum ki hasta yiyor verilen kurala uymuyor o durumda verdiğim emeğin boşa gittiğini düşünüyorum, boşa giden bir şey var bu durum da mutsuz oluyorum üzülüyorum". Diğer bir ifadesinde "Victor Hugo'nun bir sözü var vicdan insanın içindeki tanrıdır diye, etkiler beni bu cümle tedavi hazırlarken yanımda kimse yok kuralına göre kendi vicdani duygumla en doğru en dürüst şekilde yapmaya çalı̧ıyorum yapmazsam rahatsiz olurum"

H.7. H.8 ve H.9 ifadelerinde tükenmişlik ve üzüntü yaşadıklarını davranışlarında mesleki ve etik değerlerin etkili olduğunu ifade ediyorlar. 


\section{Sonuç ve Tartışma}

$\mathrm{Bu}$ çalışmanın sonucunda sağlık çalışanlarından hemşirelerde oluşan duygusal emek gösterimi esnasındaki duygu durumları derinlemesine araştırılarak çeşitli yorumlamalarda bulunulabilir. Her insanın olayları algılamaları ve verdikleri tepkiler birbirlerinden çok farklı olarak gerçekleşmektedir (Keçeli 2019,s.1). Öncelikle hemşirelerin literatürde bahsi geçen duygu durumlarını yansıtacak şekilde davrandıkları görülmüştür. Morris ve Feldman $(1996$, s.987) yapmış olduğu çalışmayı destekler nitelikte çaba kontrol ve planlamanın yapıldığ bir başka deyişle hem durumsal hem de ani oluştuğunu bütün görüşmeciler ifade etmişlerdir.

Duygusal emeğin boyutları açısından Basım ve Beğenirbaş (2012,s. 77), Hochschild'ın (1983,s.7-9) çalışmalarında da bahsettiği şekilde yüzeysel derin ve samimi davranış şeklinde oluşan duygu durumundan H.1, H.2, H.3,H.4, H.5 kodlu görüşmecilerde oluştuğunu ifade etmiş H.3, H.4, H.6, H.9 kodlu görüşmeciler ise samimi davranıştan söz etmemiştir.

Duygusal emek gösterimindeki yüzeysel davranış Hochschild (1983,s.79) tarafından sahte davranış şekli olarak da tanımlamışlardır fakat sağlık sektöründeki ifadeler incelendiğinde katılımcıların sahte davranış demekten özellikle kaçındıkları görülmüştür. Bu durum da sağlık sektöründeki özel durumdan yani hastanın bir müşteri gibi görülemediğinden kaynaklandığı düşünülmektedir. Yine aynı şekilde samimi davranışın az gösteriliyor olması da bu duruma bağlanabilir.

Duygusal emek davranışının sebep ve sonuçları açısından incelendiğinde ise literatürdeki çoğu araştırmacı tarafından dile getirilen etkilerinin olduğu söylenmiştir (Aslan ve Çaldağ, 2011, s.39; Hochschild, 1979, s.572; Oral ve Köse, 2011, s.473; Seçer, 2012, s.265). Kodlar ve temalar çerçevesinde yapılan incelemede mutluluk, tükenmişlik, vicdan meslek gereği profesyonellik gibi konuların sıklıkla ifade edildiği gözlenmiştir. Bu çalışmanın önemli bulgularından bir tanesi de özellikle Türkçe literatürde bahsedilmemiş H.5 görüşmeci hariç tüm görüşmecilerin ifadelerinde bulunan vicdan ve merhamet duygusunu öne çktığ gözlenmiştir. Bu durum duygusal emek davranışının kurumun veya işin gereği oluşan duygu durumundan çok kişisel özelliklerin etkili olduğu şeklinde yorumlanabilir. 
Katılımciların konu ettikleri bir diğer alan ise hasta yükü olmuştur. Hasta sayısının fazla olması hastalara karşı duygularını kullanırken olumsuz etkilediği bu açıdan bakıldığında kurumun hasta yükünün belli standartlarda tutmasının çalışanların menfaatine olacağı şeklinde değerlendirilmektedir.

Ayrıca tükenmişlik ile ilgili ifadeler incelendiğinde hasta ile geçirilen süre ve mesleki kıdem ile deneyimin belli zamanı aştı̆̆ durumlardan sonra tükenmişlik oluştuğunu ifade eden görüşmeciler için belirli zaman aralıklarında klinikler arası rotasyona tabi tutulmaları ve/veya uzun süreli tatile çıkmaları tükenmişlikleri için olumlu etki edeceği düşünülmektedir.

Genelde örgütsel davranış özelde ise duygusal emek davranışı ile ilgili çeşitli eğitimler verilmesinin çalışanların bilgi ve davranışlarında etki edeceği beklenmektedir bu yönüyle duygusal emek ile ilgili çeşitli eğitimlerin verilmesi önerilebilir.

Bu tespitlerin yanında H.1 H.2 H.6 H.7 kodlu görüşmeciler hasta yükünün fazla olmasının davranışlarına olumsuz etki yaptığını ifade etmişlerdir. Ayrıca hasta her zaman haklıdır ve/veya hasta memnuniyeti her zaman ön planda tutulmalıdır anlayışı da çalışanların davranışlarında olumlu ve olumsuz etki edeceğini ifade etmişlerdir. Bu durumun çalışanda baskı oluşturduğuna dikkat çekerek hastaların müşteri gibi algilamalarının doğru olmadığını onlara sadece hasta ve insan olarak bakılmaları gerektiğini ifade etmişlerdir.

Bu sonuçlar neticesinde duygusal emek davranışının sağlık çalışanlarında farklı algılandığı ve kişilik özelliklerinden etkilenmekle birlikte çalışılan kurumun ve hastanın durumuna göre de şekil aldığı söylenebilir. Ayrıca görüşmecilerin duygusal emek gösterimi sırasında merhamet vicdan ve mutluluk duyusunu dile getirmeleri farklı bir yorum olarak algılanabilir. Yapılan araştırma neticesinde öneri olarak ise görüşmecilerin duygusal emek davranışı hakkında eğitim ve bilgilendirmeler yapılmasının önemli olacağı değerlendirilmektedir. Bu araştırmada duygusal emek davranışını nitel yöntemler ile genel olarak ele almak amaçlanmıştır. Bundan sonra araştırmacılara daha özel konularda örneğin sadece yüzeysel davranış veya samimi davranış gibi belli konularda daha derinlemesine araştırmalar yapılması önerilebilir. 


\title{
EXTENDED ABSTRACT
}

\section{A Qualitative Research on Emotional Labor Concept in Nurses}

\author{
* \\ Bünyamin Özgüleş \\ Yunus Emre State Hospital
}

In the world we have experienced, the most challenging being to define is the inference of human beings, the most crucial feature of the emotional state of mind. The definitions of emotional labor, which consists of the combination of the most valuable and sacred concepts of labor in working life, is the way of behavior that should be done against customers. Initially described by Hoshschild (1983, p.7) as a way of showing feelings that are not felt towards customers in employees, this concept has been studied as a subject of research in the field of health, especially in the service sector (Kiyat et al., 2018, p.489). The emotional labor behavior of nurses, who are one of the first occupational groups that come to mind when it comes to health care workers, is related to the whole working life with health workers in particular how this behavior is shaped. The main goal of this research is to examine the feelings and thoughts of nurses through qualitative analysis methods to research social reality situations related to the concept of emotional labor. With the current study carried out in this context, the research was designed within the framework of the qualitative in-depth interview method with 9 nurses working in hospitals.

It is noteworthy that most of the studies in the literature have been examined through quantitative methods and via questionnaire, while the scarce qualitative studies have been observed (Kiyat et al., 2018, p.477). In this research, interviews using the semi-structured interview technique is an essential feature of this research, the participants' desire to obtain information about their knowledge and experience and to clarify the social reality related to the concept of emotional labor. In line with this reality and goals, the main problem of the research and the questions to be asked to the study group were formed as two main questions;

A. How does emotional labor behavior mean for the participants? 
B. What are the individual and institutional variables in emotional labor representation?

In the first part of the research, a preliminary study was conducted to determine the questions to be asked to the participants during the semistructured in-depth interview. At this stage, apart from the researcher, opinions were received from three academicians who are experts in their fields. The data obtained from the answers given to open-ended questions to determine their views about the emotional labor representation with 21 participants working in the same hospital, specific categories, and themes were created with the content analysis method. In this analysis process, 3 main themes and 12 codes were determined in accordance with the literature. These themes and codes cover the concepts of effort control and planning for the processes of emotional labor, superficial, in-depth, and sincere behavior for the dimensions of emotional labor, and finally, the concepts of spontaneous, situational, happiness, exhaustion, mercy for emotional labor.

Nine nurses working at a public hospital in Eskişehir province, having at least ten years of experience, communicating directly with patients and working in physical therapy and internal medicine clinics were considered as research sample groups. The purposeful sampling method (Gürbüz and Şahin 2014, p.128), which is one of the non-probable sampling types, was used in the study and 9 nurses working in 3 different clinics were included in the study. Under the purpose of the study, a semi-structured questionnaire prepared by the researcher was used. For this purpose, the relevant consent form was obtained from the participants, and interviews were conducted between November and December 2019 voluntarily.

The data obtained were presented with a descriptive approach by first quoting directly without making any changes, as the participants say, without making any changes in the original form of some expressions of the data we gathered in the research.

In this context, when the texts are examined under the light of the literature, the words that are thought to have the same meaning from 21 descriptions were removed and 12 codes were determined. These codes are themed as a process dimension and cause and result. Later, descriptive inferences and interpretations were made, including the first approach. In other words, the data were analyzed with the descriptive and content analysis methods. 
The questions we asked during the interview and the concept of emotional labor was evaluated under the light of the topics and themes mentioned in the conceptual framework. Thus, it has been observed that emotional labor is expressed in general terms such as superficial behavior, sincere behavior and deep behavioral patterns, planning in emotional labor display, sense of effort and control, and the causes and consequences of emotional labor, as well as being in the category of conscience and spiritual emotions.

As a result of this study, various interpretations can be made by thoroughly researching the emotional conditions during the emotional labor screening of health workers and nurses. First of all, it was observed that nurses behaved in a way that reflected the moods mentioned in the literature. Morris and Feldman (1996, p.987) stated that all of the interviewees stated that effort control and planning were carried out to support their work and that this planning was developed spontaneously, in other words, both situational and sudden.

Another area that the participants were talking about was the patient's burden. From this point of view, the number of patients negatively affects their feelings towards patients; it is assessed that it is in the best interests of the employees to keep the patient burden in specific standards.

As a result of these results, it can be said that emotional labor behavior is perceived differently in healthcare workers, and it is influenced by personality traits, but it also takes shape according to the situation of the institution and patient. In addition, it can be perceived that the interviewees express their sense of compassion, conscience, and happiness during the emotional labor demonstration. As a result of the research, it is considered that training and information about the emotional labor behavior of the interviewers will be relevant. In this study, it is aimed to deal with emotional labor behavior with qualitative methods in general. From now on, researchers may be offered more in-depth research on specific topics, such as only superficial behavior or intimate behavior.

\section{Kaynakça / References}

Anderson L. B. (2014) There goes another little chip of your heart: Exploring the intersections of communicatıon, emotional labor, and age. Yayınlanmamış Doktora Tezi. Purdue University. West Lafayette, Indiana. 
Ashforth B. E. ve Humphrey R. H. (1993) Emotional labor in service roles: The influence of 1dentity. Academy of Management Review 18(1), 88-115.

Aslan, Ş., ve Çaldağ, M. A. (2011). Duygusal emek davranışları. Ö. Yeniçeri, Y. Demirel (ed.), Yönetimde birey ve örgüt odakl davranışlar içinde Bursa: Ekin Basım Yayın.

Basım H. N. ve Beğenirbaş M. (2012) Çalışma yaşamında duygusal emek: Bir ölçek uyarlama çalışması. Yönetim ve Ekonomi 19(1), 77-90.

Baş, T. ve Akturan, U. (2013). Nitel araştırma yöntemleri. Ankara: Seçkin Yayınc1lik.

Chu, K. H. L. ve Murrmann, S. K. (2006). Development and validation of the hospitality emotional labor scale. Tourism Management, 27(6), 1181-1191.

Çoşkun, R.,(2019). Türkçe nitel araştırmalarda nitelik sorunu:Nitel araştırmalar ne kadar bilimsel?. 6.Uluslar arası Balkanlarda Sosyal Bilimler Kogresi, Bildiri Kitapcı̆̆ı. Moldova.

Diefendorff J. M.,Croyle M. H. ve Gosserand R. H. (2005) The dimensionality and antecedents of emotional labor strategies. Journal of Vocational Behavior, 66(2), 339-357.

Erdoğan, S., Nahçivan, N. ve Esin, N. (2014). Hemşirelikte araştırma süreç, uygulama ve kritik. İstanbul: Nobel Tip Kitabevi,.

Gabriel, A. S., Cheshin, A., Moran, C. M., ve Van Kleef, G. A. (2016). Enhancing emotional performance and customer service through human resources practices: A systems perspective. Human Resource Management Review, 26(1), 14-24.

Gök., G. A. (2015). "Presentable” duygusal emek: İlaç mümessillerinde duygusal emeğin işe bağlılı̆̆a etkisi. Eskişehir Osmangazi Üniversitesi İ̈BF Dergisi, Aralık, 10(3), 277- 300

Grandey, A. A. (2000). Emotion regulation in the workplace: A new way to conceptualize emotional labor. Journal of Occupational Health Psychology. 5(1), 95-110.

Johnson, B., ve Christensen L. (2004). Educational research: Quantitative, qualitative, and mixed approaches. Needham Heights, MA: Allyn ve Bacon.

Hochschild, A. R. (1983). The managed heart: commercialization of human feeling. Twentieth Anniversary Edition With a New Afterword, Berkeley: University of California Press.

Hochschild, A. R. (1979). Emotion work, feeling rules, and social structure. American Journal of Sociology, 85(3), 551-575. 
Gangadharan A. (2014) Can 1 smile with spirtt? Towards a process model associating work place spirtutualty and emotıonal labor. Yayınlanmamış Doktora Tezi. University of Texas-PanAmerican 45-49.

Gürbüz, S. ve Şahin, F. (2014). Sosyal bilimlerde araştırma yöntemleri. Ankara: Seçkin Yayıncilı.

Kaya, D.Ş., Yüceler,A., Uludağ,A. ve Karadağ,Ş., (2017). Hasta ilişkilerinde tıbbi sekreterlerin duygusal emek ve iletişimm becerilerinin nitel olarak değerlendirilmesi. Süleyman Demirel Üniversitesi Vizyoner Dergisi, 8(19), 6276.

Keçeli, S. (2019). Çalışan perspektifinden öğrenme yeteneğinin iş performansina etkisi: Sağllk sektörü örneği. Ankara: Iksad Publications.

Kıyat, G.B.D., Özgüleş, B., ve Günaydın, S.C. (2018), Algılanan kurumsal itibar ve işe bağlılığın duygusal emek davranışı üzerine etkisi: sağlık çalışanları örneği. Hacettepe Sağllk İdaresi Dergisi, 21(3), 473-494

Kothari, C. R. (2004). Research methodology: Methods and techniques. New Age International (P) Limited, New Delhi: Publishers (India).

Krueger, R. (2000). A focus groups: A practical guide for applied research. Thousand Oakz, CA: Sage Publications.

Kulualp,H.G. veSarı, Ö.,(2018). Duygusal emek: Okul öncesi öğretmenleri üzerine bir içerik analizi. Uluslararası Yönetim İktisat Ve İşletme Dergisi, 14(4), 1167-1181. http://dx.doi.org/10.17130/ijmeb.2018445675

Kuzel, A. J. (1992). Sampling in qualitative inquiry. In B. F. Crabtrree, W. L. Miller (Eds.), Doing qualitative research (p. 33-45). Thousand Oaks, CA: Sage Publications.

Merriam Sharen, B. (2013). Nitel araştırma desen ve uygulama için bir rehber, S. Turan (Çev.) Ankara: Nobel Yayınevi.

Morgan, D. L. (1997). Focus groups as qualitative research. Qualitative research methods series. 16. Thousand Oaks. CA: Sage Publications.

Morris, J. A., ve Feldman, D. C. (1996). The dimensions, antecedents, and consequences of emotional labor. Academy of Management Review, 21(4), 9861010.

Oral, A. G. L., ve Köse, S. (2011). Hekimlerin duygusal emek kullanımı ile iş doyumu ve tükenmişlik düzeyleri arasındaki ilişkiler üzerinde bir araştırma. Süleyman Demirel Üniversitesi İktisadi ve İdari Bilimler Fakültesi Dergisi, 16(2), 463-492. 
Seçer, H. Ş. (2005). Çalışma yaşamında duygular ve duygusal emek: Sosyoloji, psikoloji ve örgüt teorisi açısından bir değerlendirme. Sosyal Siyaset Konferansları Dergisi, 50, 813-834.

Seçer, H. Ş. (2012). Duygusal emek: Teorik yaklaşımlar, işleyiş ve sonuçları. A. Keser, G. Yılmaz, S. Yürür (ed.), Çalışma yaşamında davranış: Güncel yaklaşımlar. 2. Bsm, Kocaeli: Umuttepe Yayınları.

Sönmez, V. ve Alacapınar, G., F. (2016). Örneklendirilmiş bilimsel araştırma yöntemleri. Ankara: Anı Yayınclik.

Uzuntarla, Y. (2015). Kişilik özellikleri ile empatik özellikler arasındaki ilişkide duygusal emek ve tükenmişliğin aracılık rolü: Hekimler üzerine bir araştırma. Yayınlanmamış Doktora Tezi. Ankara: GATA. Sağlık Hizmetleri, Yönetimi Ana Bilim Dalı.

\section{Kaynakça Bilgisi / Citation Information}

Özgüleş, B. (2020). Hemşirelerde duygusal emek kavramı üzerine nitel bir araştırma. OPUS-Uluslararası Toplum Araştırmaları Dergisi, 15(26), 4046-4069. DOI: 10.26466/opus.678995 